Journal of

Food and Nutrition

Review Article

Open Access

\title{
Combating Obesity: Utilizing Natural and Chemical Compounds for Lipid Modifica- tion- A Mini-Review
}

\section{Rabia Durrani*}

School of Biology and Biological Engineering South China University of Technology 382 East Outer Loop Rd, University Park, Guangzhou, Guangdong, China

${ }^{\star}$ Corresponding author: Rabia Durrani, School of Biology and Biological Engineering South China University of Technology 382 East Outer Loop Rd, University Park, Guangzhou,Guangdong 510006, China, Email: rabiadurrani_kust@yahoo.co.uk

Received Date: April 30, 2021 Accepted Date: May 30, 2021 Published Date: June 02, 2021

Citation: Rabia Durrani (2021) Combating Obesity: Utilizing Natural and Chemical Compounds for Lipid Modification- A Mini-Review. J Food Nutr 7: 1-12

\begin{abstract}
Lipids play important biological functions such as maintenance of the cell integrity, storage for energy metabolism and as signaling molecules. Changes in lipid metabolic pathways can either lead to therapeutic benefits or cause illness. Anti-obesity drugs for example down regulate the digestion of dietary triglycerides minimizing their uptake and thereby treat chronic obesity. Pancreatic lipase plays a central role in this process and therefore represents the preferred target for anti-obesity drugs. In the past years, a broad range of natural and synthetic pancreatic lipase inhibitors have been described. In this contribution, we aim at giving a structured overview over the diversity of these drugs, illuminate their mode of action and critically discuss their undesired side effects. We recommended that further investigations are warranted to ascertain the efficacy, safety and pharmacological potential of herbal medicines. Medicinal herbs must be tested for bioactivity and toxicity to make marketed formulation and standardization.
\end{abstract}

Keywords: Pancreatic Lipase; High throughput screening (HTS); Glycosides; Polyphenols; Polysaccharides; Saponins; Pancreatic lipase inhibitors (PLIs)

List of Abbreviations: THL: Tetrahydrolipstatin; T2DM: (type 2 diabetes mellitus); GLP1: Glucagon-like Peptide 1; CB1: Cannabinoid-1; SAR: Structure activity relationship; HTS: High Throughput Screening

(C)2021 The Authors. Published by the JScholar under the terms of the Creative Commons Attribution License http://creativecommons.org/licenses/ by $/ 3.0 /$, which permits unrestricted use, provided the original author and source are credited. 


\section{Introduction}

Obesity is becoming a major global health threat [1] causing insulin imbalance, heart attacks or abnormal cell proliferation [2]. Most obese patients suffer from chronic inflammation, hypertension and insulin abnormality [3,4], heart attacks and strokes, bones and joints inflammation, diabetes and cancer [5-7]. A reduction of the body weight by only $>5 \%$ already significantly decreases the risks for cardiovascular diseases and type 2 diabetes mellitus (T2DM) [8,9]. To achieve this reduction of body weight, surgery through gastric bypass is an effective method [10], but is expensive and physically invasive. Early drugs such as fenfluramine, sibutramine and rimonabant had more severe side effects like cardiovascular disease, hypertension, blood pressure, mood changes, and have been thus eradicated from the market [11]. Today, Orlistat is widely used for longterm anti-osteogenesis treatment inducing annual weight losses of to $3 \%$ [8]. However, even Orlistat presents severe, undesired side-effects. Molecules that mimic endogenous peptides like glucagon-like peptide 1 (GLP1) characterize alternative potential types of anti-osteogenic drugs, but these require intravenous, intranasal or subacute admission. Furthermore, they are quickly absorbed by the body and their long-term effectiveness remains elusive [12,13]. Overall, there is an ongoing need for efficient, simple and safe treatments to fight obesity. In this review article, we have provided a detailed overview of the diversity of some current anti-obesity drugs and illuminate their mode of action and critically discussed their possible undesired side effects.

\section{Currently available anti-obesity drugs}

\section{Sibutramine}

It is a phenethylamine class of anti-obesity drug that has been approved for long term treatment of obesity in adult pa- tients. It reduces food intake by selective inhibition and reuptake of noradrenaline, serotonin, and dopamine resulting in lipolysis. The common side effects of these drugs are dry mouth, constipation, headache, anorexia and palpitation [14].

\section{Orlistat}

This anti-obesity drug is an inhibitor of gastric and pancreatic lipase. It is a hydrogenated form of lipstatin, isolated from Streptomyces toxytricini. It makes a covalent bond with the serine active site of pancreatic lipase and reduces dietary fats absorption. Its common side effects are abdominal cramping and some fat soluble vitamins elimination [15].

\section{Rimonabant}

In the human body, appetite regulation involves cannabinoid -1 receptors $\left(\mathrm{CB}_{1}\right)$, which upon stimulation increase demand of food. Rimonabant blocks $\left(\mathrm{CB}_{1}\right)$ receptors and raises thermogenesis. Its unusual side effects include nausea, vomiting, diarrhea, headache and anxiety [16].

\section{Lorcaserin}

This drug is a $5-\mathrm{HT}_{2 \mathrm{C}}$ receptor antagonist and has serotonergic properties. These receptors are located in various parts of the human brain and upon activation result in weight loss through hypophagia [17]. Other antiobesity drugs include phendimetrazine, diethylpropion, methamphetamine, phentermine and topiramate [14]. The structure and mechanism of action of each of the formerly described drugs are shown in Table 1 and Figure 1 respectively.

Table 1. Current anti-obesity drugs [18]

\begin{tabular}{|l|l|l|}
\hline Drug & Mechanism & References \\
\hline Sibutramine (phenethylamine class of drug) & $\begin{array}{l}\text { Inhibition and reuptake of noradrenaline, } \\
\text { serotonin and dopamine. }\end{array}$ & (Elangbam, 2009) \\
\hline Orlistat (Streptomyces toxytricini) & Pancreatic Lipase Inhibitor & (Kaila and Raman, 2008) \\
\hline Rimonabant & $\mathrm{CB}_{1}$ cannabinoid receptor antagonist & (Kaila and Raman, 2008) \\
\hline Lorcaserin & $5-\mathrm{HT}_{2 \mathrm{C}}$ receptors in brain & (Lam, et al., 2008) \\
\hline ATL- 962 (cetilistat) In clinical trials & Pancreatic Lipase Inhibitor & (Chen, et al., 2017) \\
\hline GT389-255 In clinical trials & Lipase Inhibitor & (Chen, et al., 2017) \\
\hline
\end{tabular}




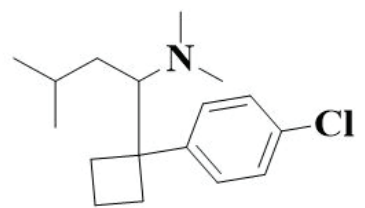

Sibutramine<smiles>CC1CNCCc2ccc(Cl)cc21</smiles>

Lorcaserin<smiles>CCN(CC)C(C)C(=O)c1ccccc1</smiles>

Diethylpropion

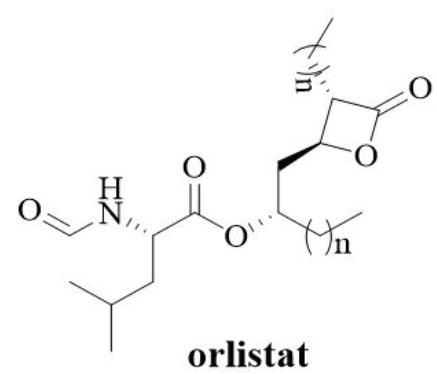<smiles>CC1C(c2ccccc2)OCCN1C</smiles>

phendimetrazine<smiles>CNC(C)Cc1ccccc1</smiles>

methamphetamine<smiles>Cc1c(C(=O)NN2CCCCC2)nn(-c2ccc(Cl)cc2Cl)c1-c1ccc(Cl)cc1</smiles>

Rimonabant<smiles>CC1(C)OC2COC3(COS(N)(=O)=O)OC(O3)C2O1</smiles>

topiramate<smiles>CC(C)(N)Cc1ccccc1</smiles>

phentermine

Figure 1. Structures of anti-obesity drugs (Lunagariya et al., 2014)

\section{Mechanism of Pancreatic Lipase in Lipid digestion and Absorption}

To completely understand the process of lipid homeostasis such as absorption, metabolism, transfer, storage, deposition and oxidation presents a broad range of enzymatic targets involved. Schematic representation of dietary fats metabolism by pancreatic lipase is shown in figure 2. Dietary fats consist of mixtures of triglyceride that undergoes a chain of biochemical reactions before being absorbed into the gastrointestinal cavity. Pancreatic, endothelial, hepatic and lipoprotein are human lipases having structural similarity. Other organs like lungs, kidney, muscles, adipose tissue and placenta also secrete lipases. Pancreatic acinar cells secrete a pancreatic lipase (triglycerol acyl hydrolase EC 3.1.1.3) that is a vital pancreatic secretion for digestion of dietary triglycerides in the small intestine. The pancreatic lipase interacts with emulsion droplets that change its physical properties when formed by leaving the surface during hydrolysis. Complete hydrolysis results in free fatty acids, monoacylglycerols, diacylglycerols that bind cholesterol molecules, bile, fat soluble vitamins and lysophosphatidic acid to form mixed micelles that are easily absorbed by enterocytes. Pancreatic lipase works by using colipase as a cofactor for lipolytic action. It reverses the inhibitory action and facilitates pancreatic lipase to interact with the surface of the substrate stabilizing the conformation (Lunagariya et al., 2014) [16].

\section{Different approaches concerning Pancreatic Lipase In- hibition}

The pancreatic lipase inhibition is extensively studied in order to identify a potential anti-obesity drug. The only approved drug by FDA for treating obesity is Orlistat, a potent inhibitor of pancreatic lipase activity. Orlistat was discovered from the natural molecule lipstatin, which was then synthetically synthesized and present side effects. This has motivated researchers to identify better pancreatic lipase inhibitors that lack unpleasant side effects. Until now, many herbal extracts and their compounds are screened for pancreatic lipase inhibitory activity. Moreover, several microbial compounds and isolated compounds, protamines, $\varepsilon$-polylysines, dietary fibers from wheat bran, soya proteins and synthetic compounds have been studied for pancreatic lipase inhibition. Nonetheless, plant and microbial sources are focused mostly in research and reported for pancreatic lipase inhibitory activity.

\section{Different phytochemicals as a source of Pancreatic lipase in- hibitors}

In order to identify biologically potent pancreatic lipase inhibitors, such as anti-obesity agents from natural sources, several plant extracts and their phytochemicals have been screened for lipase inhibitory action. In Table 2 there is a summarized list of phytochemicals and their structure. 


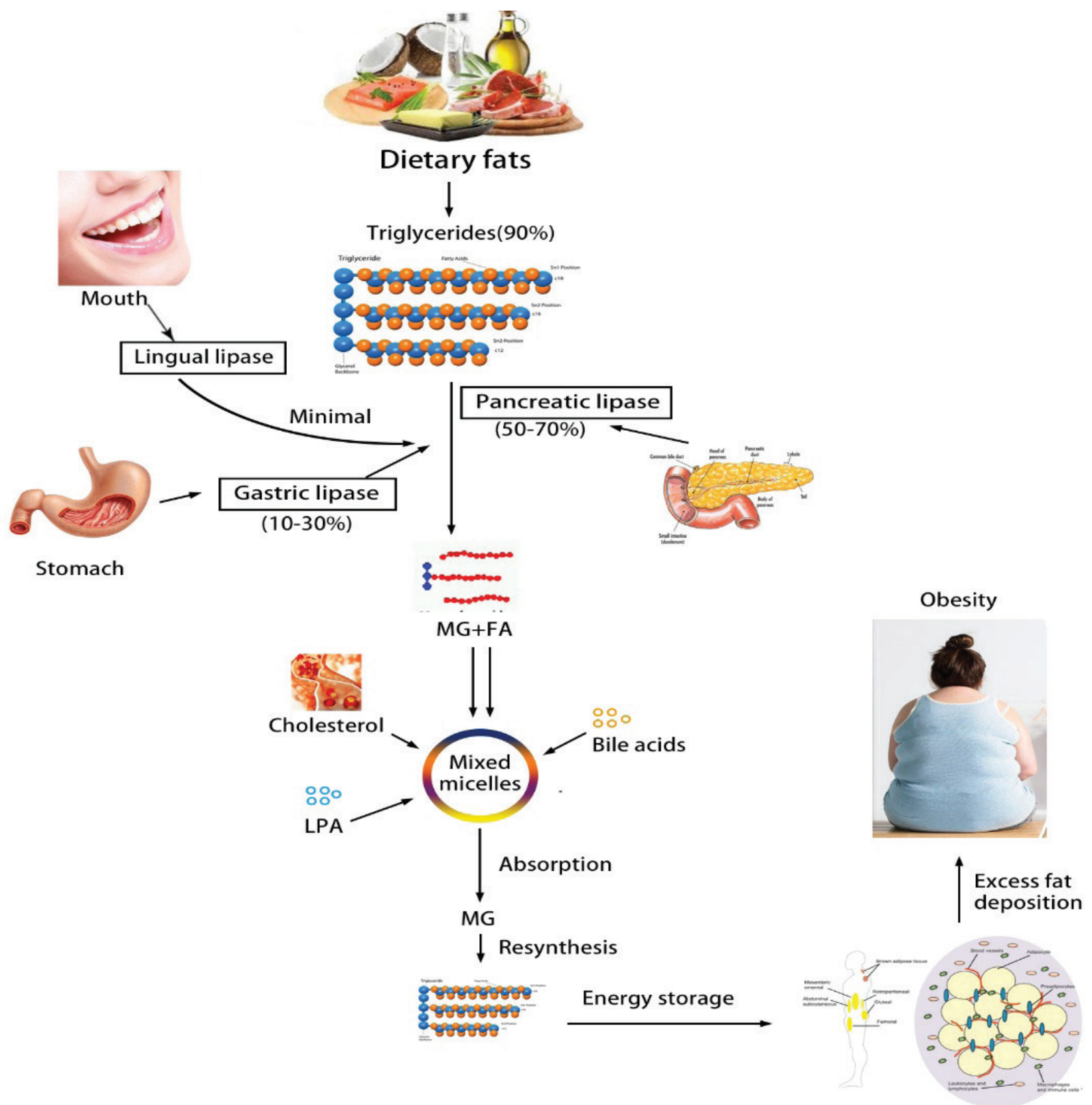

Adipose

tissue

Figure 2. Mechanism of dietary fats metabolism by pancreatic lipase.The nutrient digestion and absorption should be decreased in order to reduce energy intake [18] 
Table 2. Selection of phytochemicals and their anti-obesity effects

\begin{tabular}{|c|c|c|c|}
\hline Phytochemicals & Compounds & Mode of Action & Reference \\
\hline Carotenoids & $\begin{array}{l}\text { Fucoxanthin (edible seaweeds) and its metabolite } \\
\text { fucoxanthinol }\end{array}$ & $\begin{array}{l}\text { Reduction in triglyceride absorp- } \\
\text { tion and suppression in increase in } \\
\text { triglyceride concentration in blood } \\
\text { in rat pancreatic lipase. }\end{array}$ & $\begin{array}{l}\text { (Matsumoto } \\
\text { et al., 2010) }\end{array}$ \\
\hline Glycosides & $\begin{array}{l}\text { Acteoside, kaempferol-3O-rutinoside, rutin, kaemp- } \\
\text { ferol, quercetin, and Luteolin. Luteolin-6-C- } \beta \text {-D-bo- } \\
\text { vinopyranoside, orientin, isoorientin, derhamno- } \\
\text { syl-maysin, and isoorientin-2-O- } \alpha \text { - L-rhamnoside. }\end{array}$ & Fat-lowering effect in vivo. & $\begin{array}{l}\text { (Birari et al., } \\
\text { 2011) }\end{array}$ \\
\hline Polyphenols & $\begin{array}{l}\text { Galangin, Hesperidin, neohesperidin, nariru- } \\
\text { tin, naringin, 3-O-caffeoyl-4-O-galloyl-L-thre- } \\
\text { onic acid, methyl chlorogenate, Licochalcone A, } \\
\text { CT-II, Dimeric falavan(2S)-3,4,7-trihydroxyfla- } \\
\text { van-(4a } \rightarrow 8) \text {-catechin, 7-Phloroeckol, Isoliquiriti- } \\
\text { genin and 3,3,4,4-tetrahydroxy-2-methoxychal- } \\
\text { cone, Isoliquiritigenin, procyanidin contains (+) } \\
\text { - catechin, (-)-epicatechin, phloridzin, and phlore- } \\
\text { tin-2'-xyloglucoside, Flavan- 3-ol monogallate es- } \\
\text { ters, (-)-epigallocatechin- 3-O-gallate (EGCG), } \\
\text { (-)-epigallocatechin-3, 5- digallate }\end{array}$ & $\begin{array}{l}\text { The compounds bind by polyvalent } \\
\text { sites present in them and inhibits } \\
\text { pancreatic lipase. }\end{array}$ & $\begin{array}{l}\text { (Kumar et al., } \\
\text { 2013) (Lee et } \\
\text { al., 2010) }\end{array}$ \\
\hline Polysaccharides & $\begin{array}{l}\text { Chitosan (Linear polysaccharide with } \beta-(1-4) \text { linked } \\
\text { D-glucosamine (acetylated unit) }\end{array}$ & $\begin{array}{l}\text { Increases in fecal fat excretion and } \\
\text { decreases in absorption of dietary } \\
\text { lipids and inhibits pancreatic lipase }\end{array}$ & $\begin{array}{l}\text { (Sumiyoshi } \\
\text { and Kimura, } \\
\text { 2006) }\end{array}$ \\
\hline Saponins & $\begin{array}{l}\text { Sessiloside, chiisanoside(lupane type)silphioside } \\
\text { F, copteroside B, hederagenin 3-O- } \beta \text {-D-glucuron- } \\
\text { opyranoside 6-O-methyl ester, gypsogenin 3-O- } \beta \text { - } \\
\text { D-glucuronopyranoside, cyclocarioside A, II, III, } \\
\text { platycodin D, Chikusetsusaponin III \& IV, 28-deglu- } \\
\text { cosyl-chikusetsusaponins IV, ginsenosides, Escins, } \\
\text { deacetylescins and desacylescins, Scabiosaponin } \\
\text { E-G, scabiosaponin I, hookeroside A and B, pro- } \\
\text { sapogenin 1b, olong tea saponins, Dioscin, diosgen- } \\
\text { in, prosapogenin A \& C, gracillin }\end{array}$ & $\begin{array}{l}\text { Reduces triglycerides level in plas- } \\
\text { ma and inhibits pancreatic lipase }\end{array}$ & $\begin{array}{l}\text { (Lunagariya et } \\
\text { al., 2014) }\end{array}$ \\
\hline Terpenes & $\begin{array}{l}\text { Crocin and metabolite crocetin, ursolic acid, 23-hy- } \\
\text { droxyurosolic acid, corosolic acid, betulinic acid }\end{array}$ & $\begin{array}{l}\text { Reduction of serum triglycerides } \\
\text { and reduction in body weight }\end{array}$ & $\begin{array}{l}\text { (Lunagariya et } \\
\text { al., 2014) }\end{array}$ \\
\hline
\end{tabular}


Black tea polyphenols as successful pancreatic lipase inhibitors

Black tea is the most common tea consumed approximately $80 \%$ worldwide. Theaflavins and thearubigins are the common polyphenols present in black tea. Many animal models and epidemiological studies have showen that efficiency of treating obesity and weight management. Black tea polyphenols reduce serum concentration of triglycerides when administered to rats with high fat diet. The inhibitory effects of the gallate

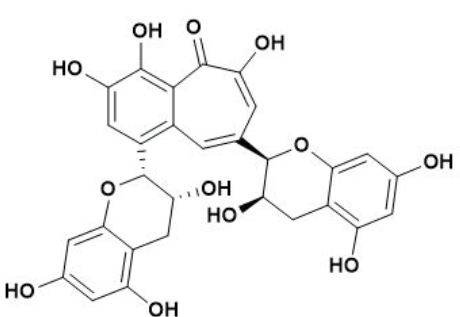

theaflavin

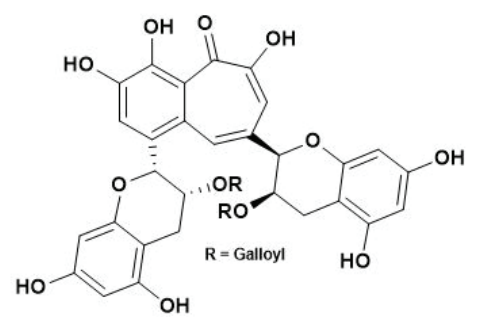

theaflavin-3,3'-O-gallate

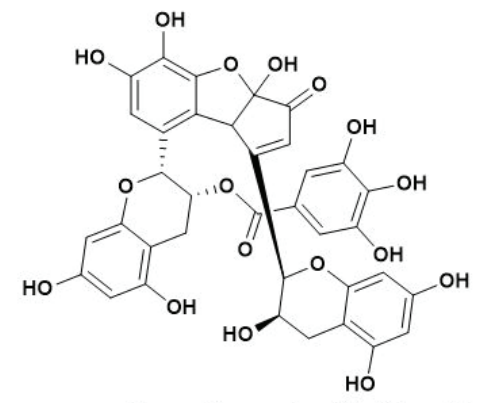

oolongtheanin-3'-O-gallate<smiles>Oc1cccc([C]2Oc3cc(O)cc(O)c3C[C@H]2O)c1</smiles>

$(+)$-epicatechin<smiles>Oc1cc(O)c2c(c1)O[C@H](c1ccc(O)c(O)c1)C[C@@H]2O</smiles><smiles>Oc1cc(O)c2c(c1)O[C@H](c1cc(O)c(O)c(O)c1)[C@H](O)C2</smiles>

(-)-epigallocatechin<smiles>O=C(Oc1cc(O)cc2c1C[C@@H](OC(=O)c1cc(O)c(O)c(O)c1)[C@H](c1ccc(O)c(O)c1)O2)c1cc(O)c(O)c(O)c1</smiles>

(-)-epigallocatechin-3,5-O-digallate<smiles>Oc1cc(O)c2c(c1)O[C](c1ccc(O)c(O)c1)[C@H](O)C2</smiles>

$(+)$-catechin<smiles>O=C(O[C@H]1Cc2c(O)cc(O)cc2O[C@H]1c1cc(O)c(O)c(O)c1)c1cc(O)c(O)c(O)c1</smiles>

(-)-epigallocatechin-3-O-gallate $(+)$-gallocatechin<smiles>Oc1cc(O)c2c(c1)O[C@H](c1ccc(O)c(O)c1)[C@H](O)C2</smiles>

(-)-epicatechin

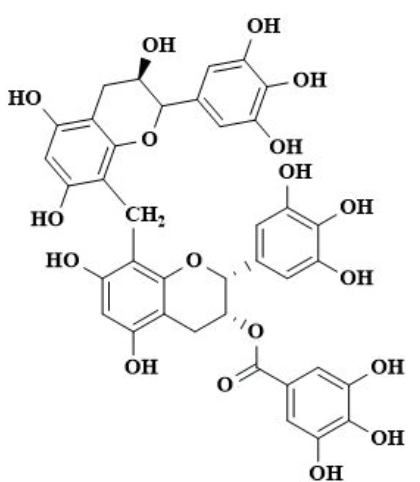

monodesgalloyl<smiles>O=C(O[C@@H]1COc2c(Cc3c(O)cc(O)c4c3OC(c3cc(O)c(O)c(O)c3)C[C@@H]4OC(=O)c3cc(O)c(O)c(O)c3)c(O)cc(O)c2C1)c1cc(O)c(O)c(O)c1</smiles>

Olong homobisflavan A 


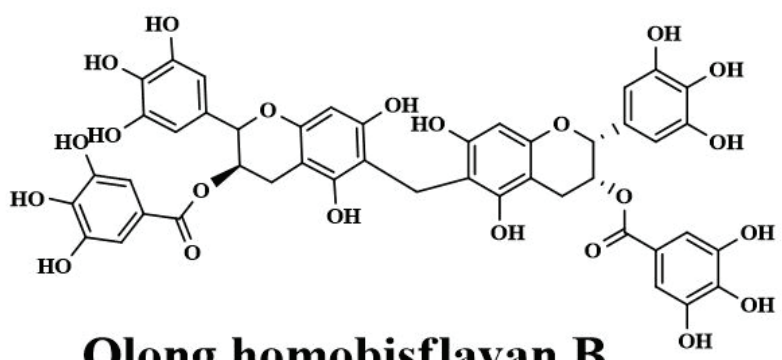

Olong homobisflavan B

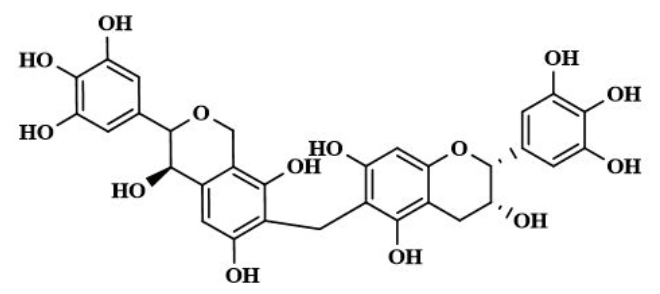

didesgalloyl

Figure 3: Chemical structures of some important phytochemicals from different sources

Natural Products are always a better source for development of new therapeutics. These compounds have an advantageous chemo-diversity and are shown in detail in figure 3. Several reported phytochemicals like saponins, terpenes, phenolics, have shown profound pancreatic lipase inhibition. A continuous research is going on to develop better inhibitor for pancreatic lipase but unfortunately no natural molecule has reached clinical studies. Therefore, improvement in the bioavailability of natural molecules is desired for improvement of therapeutic strategies.

\section{Microbes as a source for pancreatic lipase inhibition}

Microorganisms also produce bioactive compounds that are useful in treating various diseases. Lipstatin is the precursor of the Orlistat, that was first reported as pancreatic lipase inhibitor from microbial origin. It resulted to be the first approved drug by FDA for obesity treatment. This encourages scientists worldwide to explore microbial flora to explore better and cost-effectively anti-obesity agents. Lipstatin, isolated from Streptomyces toxytricini, irreversibly inhibited the pancreatic lipase. $\beta$ - lactone cleavage of lipstatin and its products resulted in no inhibition of pancreatic lipase.

There are other potential pancreatic lipase inhibitors beside lipstatin that come from microbial sources such as metabolites of $\beta$ - lactone (valilactone, percyquinin, panclicin $\mathrm{A}-\mathrm{E}$, ebelactone $\mathrm{A}$ and $\mathrm{B}$, vibralactone and esterastin) and non- $\beta$ lactone metabolites ( (E) -4-amino styryl acetate, $\varepsilon$-polylysine and caulerpenyne), all detailed in Figure 4.

Panclicins A-E isolated from Streptomyces sp. NR 0619 are effective irreversible pancreatic lipase inhibitors. Ebelactone A and B isolated from Actinomycetes strain G7-G1 showed inhibition of hog pancreatic lipase as well as vibralactone, from the Boreostereum vibrans. $\varepsilon$-polylysine is a natural polymer of L-lysine from Streptomyces albulus that strongly shows inhibits pancreatic lipase by hydrolysis of trioleoylglycerol while decreasing plasma triacylglycerol and cholesterol levels. Caulerpenyne, iso- lated from marine algae Caulerpa taxifolia, also shows inhibitory potential of pancreatic lipase and reduces plasma triglyceride levels when co-administered with corn oil.

Despite of the extensive research going on with microbial isolates as potential Pancreatic lipase inhibitors, no satisfactory treatment reached clinical studies. Thus, there is a need to update studies on known Pancreatic lipase inhibitors as well as to discover new ones, to understand their potential as better therapeutics.

\section{Synthetic Pancreatic Lipase Inhibitors}

The synthesis of synthetic pancreatic lipase inhibitors depends on the structure of natural substrate of lipase such as triglycerides, 1, 3-diaminopropan-2-ol, 2-amino alcohol, glycerol and 2-methylglycerol are employed as the backbone to form triglyceride molecules with modification in ester or amide or ether linkages. Bis-2-oxo amide triglycerols, are synthetically prepared by suing 1,3-diaminopropan-2-ol and they are efficient human pancreatic lipase inhibitors. 2-[(2-oxohexadecanoyl amino]-1-[[2-oxohexadecanoyl)-amino methyl] ethyl decanoate is a potent inhibitor of pancreatic lipase. Structure-activity relationship studies suggest that synthetic derivatives are dependent on the nature of functional groups like ester or ether and chain length at the $s n-2$ position. Hamdan et al studied twenty-five pharmaceutical structurally different compounds for pancreatic lipase inhibition. Compounds that were employed for inhibitory action by structure-activity studies were of different profiles. When these compounds were co-incubated with Orlistat, some compounds showed synergistic effects (orphenadrine, gliclazide, cefuroxime, sulfacetamide) while few compounds demonstrated antagonistic effects (camphor sulfonic acid and dinitrosalicyclic acid). 


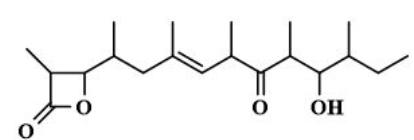

ebilactone A

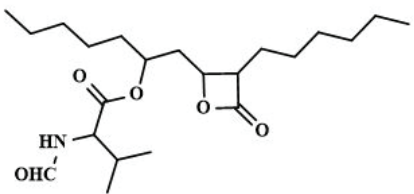

Valilactone

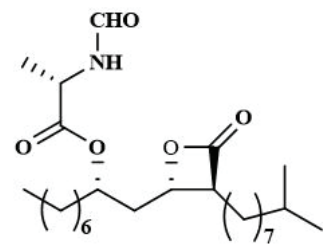

panclicin A

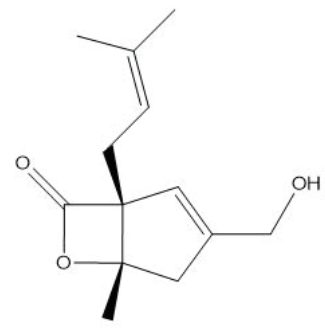

Vibralactone

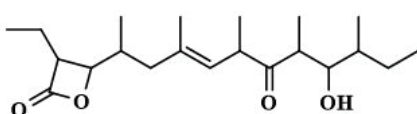

ebilactone B

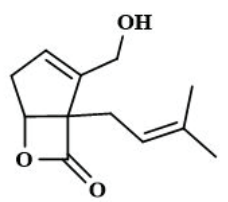

percyquinin

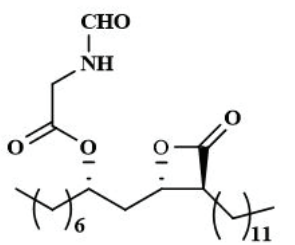

panclicin $\mathbf{E}$

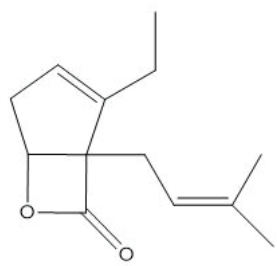

Percyquinin
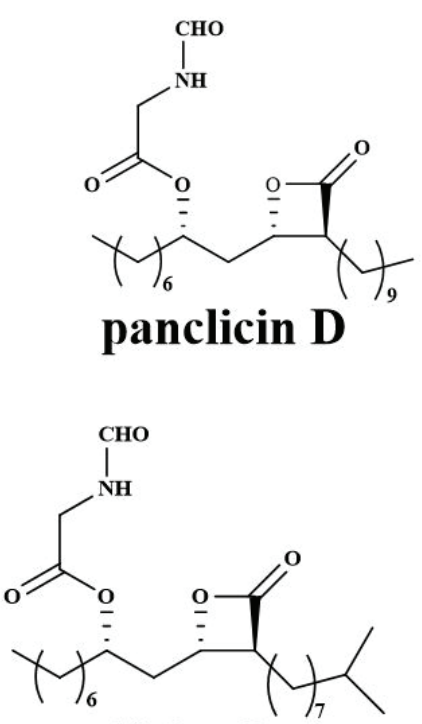

panclicin $\mathrm{C}$

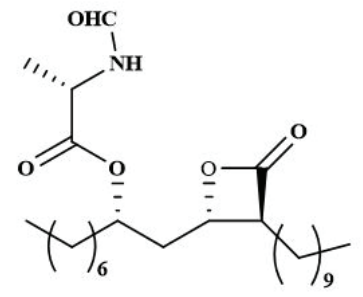

panclicin B

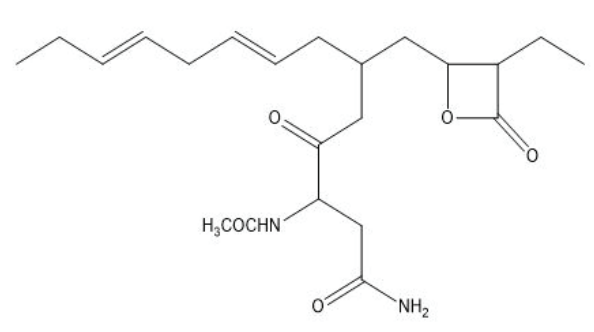

Esterastin

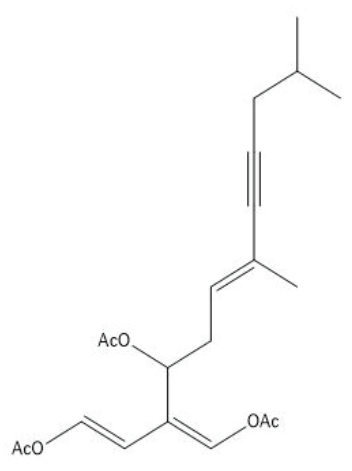

Caulerpenyne

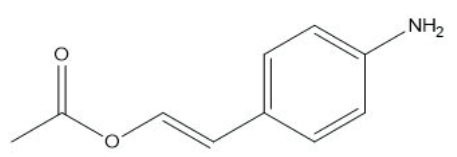

(E)-4-amino styryl acetate

Figure 4: Chemical structures of pancreatic lipase inhibitors from microbial source 
Alkyl $\alpha$ - keto amides and $\alpha$ - keto acids are shown have inhibitory action on porcine pancreatic lipase as well as Triacylglycerols analogues such as 2- (N-tert-butoxycarbonyl-amino. Triolein analogues consisting of butyl or methyl groups have also shown inhibitory action. Amongst all, a dihydroxybenzomacrolide is also described as effective pancreatic lipase inhibitor (Constantinou-Kokotou et al., 2004). The chemical structures of the synthetic pancreatic lipase inhibitors previously described are depicted in figure 5 .

Fragment based drug designing of synthetic compounds can be done to potentially open new gate ways for pancreatic lipase inhibitory activities [19].<smiles>CC(C)(C)C=CC(=O)NC(=O)COCC(C)(C)C</smiles>

Lipophilic alpha keto amide

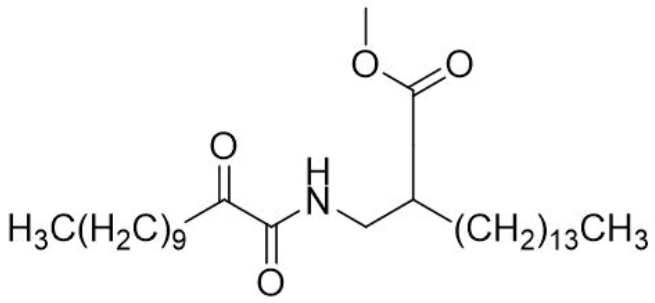

Methyl 2- [(2- ketododecanoyl) amino] hexadecanoate

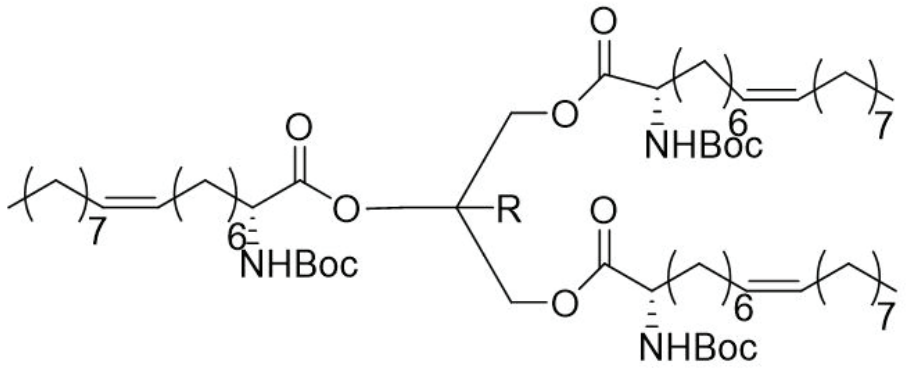

2-methylglycerol having 2-(N-tert-butoxycarbonylamino) oleic acid

Figure 5: Chemical structures of synthetic pancreatic lipase inhibitors

\section{Ongoing clinical investigations on pancreatic lipase inhibitors}

Several pancreatic lipase inhibitors are in clinical trials stage but only one has completed and it is approved i.e Cetilistat. A bio-pharmaceutical company with Takeda pharmaceutical has submitted this drug for treating obesity. It has the same mode of action as Orlistat as it inhibits the breakdown of triglycerides, but it also has unpleasant side effects. It is a new, orally gastrointestinal and pancreatic lipase inhibitor. In vitro studies showed that cetilistat inhibited human pancreatic lipase with an $\mathrm{IC}_{50}$ in the less nanomolar limit. During phase II trials in obese and type 2 diabetes patients it has remarkably showed better results in reducing body weight, low density lipoproteins (LDL) and cholestrol level. In obese diabetic patients the levels of glycosylated hemoglobin (HbA1c) were also reduced. It showed some side effects of steatorrhea, but little less than Orlistat. Recently this drug has been aproved Japan for obesity treatment [19-28].
GT $389-255$ is also under clinical investigations since it is also a pancreatic lipase inhibitor and can be used for treating obesity.

\section{Conclusion}

The incidence of obesity has increased seriously during the past 25 years. Progress to develop effective anti-obesity treatment has been limited despite of the huge amount of ongoing research. The only available drug for treatment of obesity and reduced dietary intake is Orlistat, which is an inhibitor for gastrointestinal and pancreatic lipase that has severe unpleasant side effects. Hence, a nontoxic therapeutic molecule is needed as an alternative choice with less or mild side effects. Inhibitory properties of pancreatic lipase are extensively being studied by many researchers in order to discover active effect of natural molecules as anti-obesity agents. Up to date, many natural compounds from plants such as polyphenols, polysaccharides, saponins, terpenes, compounds from mushrooms, microbial isolates and synthetic ones have 
been discovered and few of them have reached clinical trials. Natural products from plants and microbes open new gates for therapeutics. Several techniques such as high throughput screening (HTS), structure-activity relationships (SAR), metabolomics, and also system biology must be adapted for screening of compounds. Structure-activity relationship paves the way for curing obesity. A wide variety of medicinal plants and their compounds have yet to be studied, but due to the lack of scientific and pharmacological figures only few are being analyzed for drug development and body weight control. In-depth investigations are required to study the efficacy, safety and pharmacological potential of herbal medicines. Medicinal herbs must be tested for bioactivity and toxicity to make marketed formulation and standardization.

\section{Acknowledgement}

The authors are also highly thankful to Analia Banacore from Department of Chemisty and Molecular Biology, Faculty of Science, University of Gothenburg for Review and Editing.

\section{Conflict of Interest}

The author declared that they have no conflict of interest. 


\section{References}

1. Caballero B (2007) The Global Epidemic of Obesity: An Overview. Epidemiologic Reviews 29: 1-5.

2. Martel J, Ojcius D, Chang CJ, Lin CS, Lu CC, et al. (2016) Anti-obesogenic and antidiabetic effects of plants and mushrooms.

3. Mcardle M, Finucane O, Connaughton R, Mcmorrow A, Roche H (2013) Mechanisms of Obesity-Induced Inflammation and Insulin Resistance: Insights into the Emerging Role of Nutritional Strategies. Frontiers in Endocrinology: 4.

5. Haslam DW, James WPT (2002) Obesity. The Lancet 366: 1197-209.

5. Visscher TL, Seidell JC (2001) The Public Health Impact of Obesity. Annual Review of Public Health, 22: 355-75.

6. Pi-Sunyer X (2009) The Medical Risks of Obesity. Postgraduate medicine, 121:21-33.

7. Guh DP, Zhang W, Bansback N, Amarsi Z, Birmingham CL, et al. (2009) The incidence of co-morbidities related to obesity and overweight: A systematic review and meta-analysis. BMC Public Health 9: 88.

8. Wing RR, Lang W, Wadden TA, Safford M, Knowler WC, et al. (2011) Benefits of Modest Weight Loss in Improving Cardiovascular Risk Factors in Overweight and Obese Individuals With Type 2 Diabetes. Diabetes Care 34: 1481-6.

9. Yanovski SZ, Yanovski JA (2014) Long-term Drug Treatment for Obesity: A Systematic and Clinical Review. JAMA 311: 74-86.

10. Bult MJF, Van Dalen T, Muller AF (2008) Surgical treatment of obesity. European Journal of Endocrinology, 158: 135-45.

11. Dietrich, M. O. \& Horvath, T. L. (2012). Limitations in anti-obesity drug development: the critical role of hunger-promoting neurons. Nat Rev Drug Discov 11: 675-91.

12. Field BCT, Chaudhri OB, Bloom SR (2009) Obesity treatment: novel peripheral targets. British J Clin Pharmacol 68: 830-43.
13. Prasad-Reddy L, Isaacs D (2015) A clinical review of GLP-1 receptor agonists: efficacy and safety in diabetes and beyond. Drugs in Context 4: 212283.

14. Elangbam CS (2009) Review paper: Current strategies in the development of anti-obesity drugs and their safety concerns. Vet Pathol, 46: 10-24.

15. Kaila B, Raman M (2008) Obesity: a review of pathogenesis and management strategies. Can J Gastroenterol, 22: 618.

16. Lunagariya NA, Patel NK, Jagtap SC, Bhutani KK (2014) Inhibitors of pancreatic lipase: state of the art and clinical perspectives. EXCLI J 13: 897-921.

17. Lam DD, Przydzial MJ, Ridley SH, Yeo GSH, Rochford JJ, et al. (2008). Serotonin 5-HT2C Receptor Agonist Promotes Hypophagia via Downstream Activation of Melanocortin $4 \mathrm{Re}$ ceptors. Endocrinology 149: 1323-8.

18. Birari RB, Bhutani KK (2007) Pancreatic lipase inhibitors from natural sources: unexplored potential. Drug Discovery Today 12: 879-89.

19. Hamdan I, Kasabri V, Alhiari Y, El-sabawi D, Zalloum H (2018) Pancreatic Lipase Inhibitory Activity Of Selected Pharmaceutical Agents. Acta Pharmaceutica: 69.

20. Chen T, Li Y, Zhang L (2017) Nine Different Chemical Species and Action Mechanisms of Pancreatic Lipase Ligands Screened Out from Forsythia suspensa Leaves All at One Time. Molecules 22: 795.

21. Constantinou-Kokotou V, Magrioti V, Verger R (2004) Sterically Hindered Triacylglycerol Analogues as Potent Inhibitors of Human Digestive Lipases. Chemistry - A European J 10: 1133-40.

22. Birari RB, Gupta S, Mohan SG (2011) Antiobesity and lipid lowering effects of Glycyrrhiza chalcones: Experimental and computational studies. Phytomedicine, 18: 795-801.

23. Lee EM, Lee S, Chung B, Cho JY, Lee I, et al. (2010) Pancreatic Lipase Inhibition by C-Glycosidic Flavones Isolated from Eremochloa ophiuroides. Molecules (Basel, Switzerland) 15: 8251-9. 
24. Lunagariya NA, Patel NK, Jagtap SC, Bhutani KK (2014) Inhibitors of pancreatic lipase: state of the art and clinical perspectives. Excli J 13: 897-921.

25. Matsumoto M, Hosokawa M, Matsukawa N, Hagio M, et al. (2010) Suppressive effects of the marine carotenoids, fucoxanthin and fucoxanthinol on triglyceride absorption in lymph duct-cannulated rats. European J Nutri 49: 243-49.

26. Sumiyoshi M, Kimura Y (2006) Low molecular weight chitosan inhibits obesity induced by feeding a high-fat diet longterm in mice. J Pharmacology 58: 201-7.

27. Gras J (2013) Cetilistat for the treatment of obesity. Drugs of today (Barcelona, Spain: 1998) 49: 755-9.

28. Kumar D, Karmase A, Jagtap S, Shekhar R, Bhutani K (2013) Pancreatic Lipase Inhibitory Activity of Cassiamin A, a Bianthraquinone from Cassia siamea. Natural product communications 8: 195-8.

Submit your manuscript to a JScholar journal and benefit from:

ब Convenient online submission

ๆ Rigorous peer review

I Immediate publication on acceptance

ศ Open access: articles freely available online

9 High visibility within the field

ब Better discount for your subsequent articles

Submit your manuscript at http://www.jscholaronline.org/submit-manuscript.php 